Provided for non-commercial research and educational use only. Not for reproduction or distribution or commercial use.

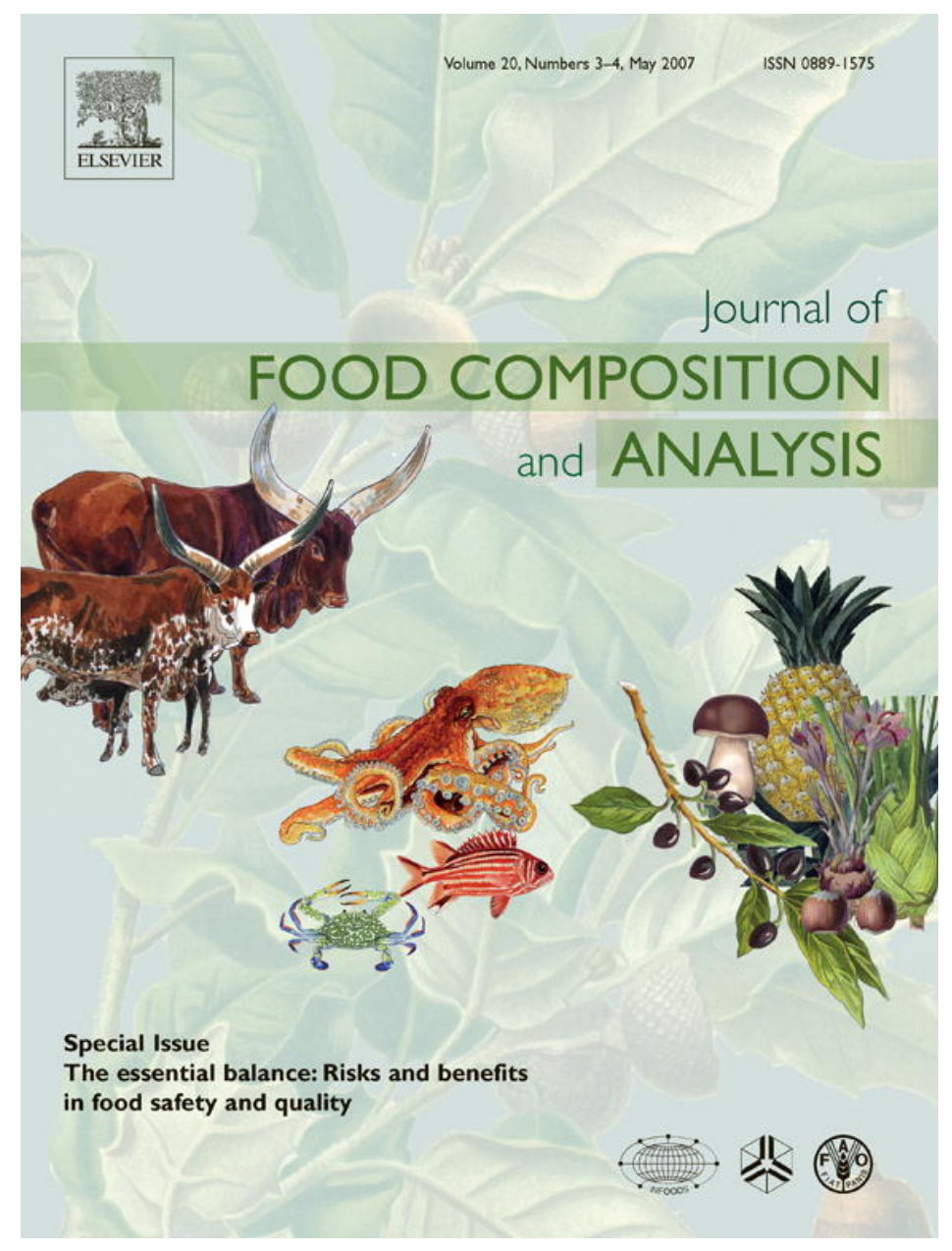

This article was originally published in a journal published by Elsevier, and the attached copy is provided by Elsevier for the author's benefit and for the benefit of the author's institution, for non-commercial research and educational use including without limitation use in instruction at your institution, sending it to specific colleagues that you know, and providing a copy to your institution's administrator.

All other uses, reproduction and distribution, including without limitation commercial reprints, selling or licensing copies or access,

or posting on open internet sites, your personal or institution's website or repository, are prohibited. For exceptions, permission may be sought for such use through Elsevier's permissions site at: 


\title{
Acrylamide levels in cooked rice, tomato sauces and some fast food on the Italian market
}

\author{
F. Tateo*, M. Bononi, G. Andreoli \\ Laboratori di Ricerche Analitiche sugli Alimenti, Di. Pro. Ve., Faculty of Agriculture, University of Milan 2, Via Celoria, 20133 Milan, Italy
}

Received 25 May 2005; received in revised form 19 July 2006; accepted 22 July 2006

\begin{abstract}
This study reports the results of evaluation of acrylamide levels in some foods that are common on the Italian market. Three foods commonly found in the national diet (rice, tomato sauce and fast food), were examined with the gas chromatograph (GC)/mass spectrometer (MS) analytical method. Results show that rice differs from risotto with respect to acrylamide levels: values of less than $50 \mu \mathrm{g} / \mathrm{kg}$, for boiled rice, increase to $113 \mu \mathrm{g} / \mathrm{kg}$ when various ingredients are added to produce risotto. Similar results were found for tomato sauce on the Italian market: acrylamide values were less than $50 \mu \mathrm{g} / \mathrm{kg}$ for simple tomato sauce, to $124 \mu \mathrm{g} / \mathrm{kg}$ when other ingredients such as olives and capers were added. Fast foods (e.g., fried potatoes) contained the highest observed acrylamide levels, probably from cooking methods and acrylamide-rich precursors. For two fried potatoes of the same type, very differentiated values resulted (136 and $294 \mu \mathrm{g} / \mathrm{kg})$.
\end{abstract}

(C) 2006 Elsevier Inc. All rights reserved.

Keywords: Acrylamide; Rice; Fast food; Tomato sauces; Food safety

\section{Introduction}

Based on numerous studies, the International Agency for Research on Cancer has classified acrylamide as "probably carcinogenic to humans" (IARC, 1994). Animal experiments have shown that acrylamide might play a role in heightened incidence of cancers of the brain and nervous system, thyroid and other endocrine glands, and reproductive organs of mice (Bull et al., 1984). In a previous study, acrylamide was shown to produce adducts with haemoglobin (Törnqvist et al., 1998). In 2002, researchers at Swedish National Food Administration and Stockholm University distributed data concerning the presence of acrylamide in several foods prepared by frying and baking (Tareke et al., 2002).

The US Food and Drug Administration (Center for Food Safety and Applied Nutrition) has begun presenting experimental data concerning the acrylamide content in a selected cluster of foods, and in 2004 the CFSAN/Office of

\footnotetext{
${ }^{*}$ Corresponding author. Tel.: 3902 50316540; fax: 390250316539.

E-mail address: fernando.tateo@unimi.it (F. Tateo).
}

Plant \& Dairy Foods posted experimental data evaluating the effects of acrylamide on the consumer for a wider spectrum of foods including bread and bread-like products, cereals and snacks (FDA, 2004). The aim of the FDA study was to evaluate the health risks associated with acrylamide consumption through food, inform the public of the FDA's progress in this area of research and stimulate research on the formation of acrylamide in food.

From the point of view of chemistry, biochemistry and the safety of acrylamide, Friedman reports that acrylamide in food is largely derived from heat-induced reactions between the amino group of the free amino acid asparagine and the carbonyl group of reducing sugars such as glucose, during baking and frying (Friedman, 2003). Other amino acids have also been found to produce low amounts of acrylamide, including alanine, arginine, aspartic acid, cysteine, glutamine, methionine, threonine and valine (Ezeji et al., 2003). Foods rich in these precursors are derived mainly from plant sources such as potatoes and cereals (barley, rice and wheat). Processed foods with high levels of acrylamide (French fries, potato chips, crispbread and various baked products and cereal formulations) show 
a wide range of acrylamide levels, both in different food categories and in different brands of the same food category. The amounts of precursors and variations in processing conditions could explain the different levels of acrylamide. Finally, the first data concerning acrylamide levels in baby food sold on the Italian market were reported in 2003 (Tateo and Bononi, 2003).

The study presented here reports data concerning foods found in the common Italian diet (rice, risotto and tomato sauce), not included in previous studies or data published by the FDA. Data concerning some fast food from the Italian market are also reported here because of the high prevalence of these foods in the diets of young people.

\section{Materials and methods}

\subsection{Chemicals}

Acrylamide $(99+\%)$ (catalog number: 14.866-0) was obtained from Sigma Aldrich (Milan, Italy); $n$-hexane $(98+\%)$, 2-propanol $(99.8 \%)$ and sodium sulphate anhydrous were obtained from Merck (Darmstadt, Germany).

\subsection{Equipment}

The quantification of acrylamide levels in food was performed on a Shimadzu 2010 gas chromatograph (GC) coupled to a Shimadzu QP2010 quadrupole mass spectrometer (MS). The GC column was a Supelcowax ${ }^{\text {TM }_{-10}}$ fused silica capillary column $(30 \mathrm{~m} \times 0.25 \mathrm{~mm}$ i.d., $0.25 \mu \mathrm{m}$ film thickness) (Supelco, Milan, Italy).

\subsection{Samples}

Two well-known Italian brands of rice were analysed after being boiled or cooked as risotto with various other ingredients commonly used for seasoning. Nine tomato sauces from the Italian market were also analysed, and four samples of each brand were considered. Ten products purchased from two well-known fast-food distributors in Milan were considered. Ingredients used to prepare all risotto samples and special ingredients declared in labels for tomato sauces are listed in Table 1.

The data reported here cover only a limited number of brands, because the aim of this work is to obtain exploratory data and not to allow absolute comparison or statistical data representative of the standard products. The same criterion was adopted by the FDA in "Exploratory data on acrylamide in food" (FDA, 2004).

\subsection{Analysis by GC/MS of acrylamide}

Samples of fast food were analysed using the original method previously published (Tateo and Bononi, 2003). In addition, the matrix was defatted with hexane at room temperature and extracted at room temperature with methanol. This method was also applied to boiled rice, risotto, and tomato sauce (Bononi et al., 2005). Approximately $10 \mathrm{~g}$ of homogenized sample was weighed and dehydrated, adding 10-50 g of sodium sulphate anhydrous, based on the water content of the sample. Each sample was defatted with $80 \mathrm{~mL}$ of hexane at room temperature, stirring for $30 \mathrm{~min}$. Most of the solvent was removed by Pasteur pipette, and the residual solvent was removed by vacuum. Some $100 \mathrm{~mL}$ of 2-propanol were added to the defatted sample in a sealed flask, then stirred for $15 \mathrm{~min}$ and shaken for $1 \mathrm{~min}$ in an ultrasonic bath. The 2-propanol phase was recovered by filtration (approximately $70 \mathrm{~mL}$ ) and subsequently concentrated in a rotary evaporator to less than $2 \mathrm{~mL}$. The residue was carefully transferred to a graduated vial, then diluted to $2 \mathrm{~mL}$ and fast filtered. Using an autosampler, $1 \mu \mathrm{L}$ of the sample was injected in splitless mode (15s) and then splitting 1:20.

The temperature program for the GC was as follows: isothermal for $1 \mathrm{~min}$ at $60^{\circ} \mathrm{C}$, increased at a rate of $5^{\circ} \mathrm{C} / \mathrm{min}$ to $240^{\circ} \mathrm{C}$, then isothermal for $10 \mathrm{~min}$. Analysis was performed using EI $(70 \mathrm{eV})$ and selected ion monitoring. The ions monitored for identification of the analyte were $m / z 55,71$ and 72 at room temperature for $22.9 \mathrm{~min}$, using $m / z 71$ for quantification.

Quantification was performed through comparison with a calibration curve $(150-1000 \mu \mathrm{g} / \mathrm{L}$ of standard acrylamide in 2-propanol) corresponding to 40 and $285 \mu \mathrm{g} / \mathrm{kg}$, if $70 \mathrm{~mL}$ of 2-propanol extract were concentrated. Corrections for percent recovery need to be made. Recovery tests were repeatedly performed by quantification of acrylamide in fresh tomato before and after the addition of acrylamide. Samples containing more than $400 \mu \mathrm{g} / \mathrm{kg}$ of acrylamide were diluted up to a factor of 2 in the first extraction step.

\section{Results}

The calibration curve was linear $\left(R^{2}=0.9926\right)$ in the $150-1000 \mu \mathrm{g} / \mathrm{kg}$ range, and the limit of detection (LOD) value was found to be $25 \mu \mathrm{g} / \mathrm{kg}$. Assuming the quantitation limit to be three times LOD, the resulting value of the limit of quantitation (LOQ) was $75 \mu \mathrm{g} / \mathrm{kg}$. However, in single ion monitoring (SIM) mode, detectable levels are evidenced at lower levels, from $50 \mu \mathrm{g} / \mathrm{kg}$ (still corrected with the recovery value). The adopted method proved useful for routine analysis, and the LOQ of $50 \mu \mathrm{g} / \mathrm{kg}$ was considered a reasonable and satisfactory target for the matrices which are the object of this work.

It is important to consider that the highest value reported for bread (the most common product in the diet) is approximately $49 \mu \mathrm{g} / \mathrm{kg}$ (Tateo and Bononi, 2003). The consumption of tomato sauce, rice and risotto in Italian diet are lower than that of bread, and for this matrix the value of $50 \mu \mathrm{g} / \mathrm{kg}$ was considered a reasonable target. For this reason, quantitation values of less than $50 \mu \mathrm{g} / \mathrm{kg}$ were not considered significant. Recovery was evaluated by quantitation of acrylamide in fresh tomato before and after the addition of acrylamide between 148 and $1049 \mu \mathrm{g} / \mathrm{kg}$. Using $50 \mathrm{~mL}$ of 2-propanol twice in the extraction step, we 
Table 1

Acrylamide levels in 27 selected foods on the Italian market $(\mu \mathrm{g} / \mathrm{kg})$

\begin{tabular}{|c|c|c|}
\hline Sample & Product & Acrylamide level $(\mu \mathrm{g} / \mathrm{kg})$ \\
\hline 1. & Rice boiled (Carnaroli superfino) ${ }^{\mathrm{a}}$ & $<50$ \\
\hline 2. & Rice boiled (Ribe parboiled $)^{\mathrm{a}}$ & $<50$ \\
\hline 3. & Risotto seasoned (Ribe parboiled ), extra-virgin olive oil, onion, stock, salt ${ }^{\mathrm{b}}$ & $<50$ \\
\hline 4. & Risotto seasoned (Ribe parboiled ), extra-virgin olive oil, dried edible fungi, onion, stock, salt ${ }^{\mathrm{b}}$ & 89 \\
\hline 5. & Risotto seasoned (Ribe parboiled), extra-virgin olive oil, pork sausages, onion, stock,salt ${ }^{\mathrm{b}}$ & 79 \\
\hline 6. & Risotto seasoned (Carnaroli superfino), extra-virgin olive oil, onion, dried edible fungi, stock, salt ${ }^{\mathrm{b}}$ & 90 \\
\hline 7. & Risotto seasoned (Carnaroli superfino), extra-virgin olive oil, pork sausages, dried edible fungi, onion, stock, salt ${ }^{\mathrm{b}}$ & 113 \\
\hline 8. & Risotto seasoned (Risotteria Knorr), mix for risotto (dried) containing saffron and edible fungi ${ }^{\mathrm{c}}$ & $<50$ \\
\hline 9. & Sauce "Pummarò" Star with fresh basil ${ }^{\mathrm{d}}$ & $<50$ \\
\hline 10. & Sauce Knorr with olives and capers ${ }^{\mathrm{d}}$ & 124 \\
\hline 11. & Sauce GS with meat ${ }^{\mathrm{d}}$ & $<50$ \\
\hline 12 & Sauce Barilla with Bolognese meat spaghetti sauce ${ }^{\mathrm{d}}$ & $<50$ \\
\hline 13. & Sauce Star concentrate ${ }^{\mathrm{d}}$ & $<50$ \\
\hline 14. & Peeled tomato Cirio ${ }^{\mathrm{d}}$ & $<50$ \\
\hline 15. & Tomato pulp Cirio ${ }^{\mathrm{d}}$ & $<50$ \\
\hline 16. & Fresh tomato variety S. Marzano ${ }^{\mathrm{e}}$ & $<50$ \\
\hline 17. & Ketchup Heinz & $<50$ \\
\hline 18. & French fries McDonald's ${ }^{\mathrm{f}}$ & 294 \\
\hline 19 & Hamburger McDonald's ${ }^{\mathrm{f}}$ & 72 \\
\hline 20. & Chicken nuggets McDonald's ${ }^{\mathrm{f}}$ & 159 \\
\hline 21. & Whole roll McDonald's, bread, hamburger, ketchup sauce, mustard, onion, cucumber ${ }^{\mathrm{f}}$ & 150 \\
\hline 22. & French fries' sauce McDonald's ${ }^{\mathrm{f}}$ & 50 \\
\hline 23. & French fries Burger King ${ }^{\mathrm{f}}$ & 136 \\
\hline 24. & Hamburger Burger King ${ }^{\mathrm{f}}$ & 127 \\
\hline 25. & Chicken nuggets Burger King ${ }^{\mathrm{f}}$ & $<50$ \\
\hline 26. & Whole roll Burger King, bread, hamburger, salad, ketchup sauce, tomatoes, cheese, onion ${ }^{\mathrm{f}}$ & 117 \\
\hline 27. & Mayonnaise sauce Burger King ${ }^{g}$ & $<50$ \\
\hline
\end{tabular}

${ }^{\text {a }}$ Samples 1, 2: two types of rice just boiled in water for $10 \mathrm{~min}$ and then strained.

${ }^{\mathrm{b}}$ Samples 3-7: rice cooked with other ingredients to make risotto.

${ }^{\mathrm{c}}$ Sample 8: mix ready to be cooked.

${ }^{\mathrm{d}}$ Samples 9-15: tomato sauces most commonly found on the Italian market.

'Samples 16, 17: fresh tomato and ketchup.

${ }^{\mathrm{f}}$ Samples 18-26: most common types of fast food

${ }^{\text {g}}$ Sample 27: mayonnaise sauce.

obtained recovery values ranging from $79 \%$ to $85 \%$. The $\mathrm{CV} \%$ values were confirmed to range from $2 \%$ to $7 \%$, in accordance with previous results (Bononi et al., 2005). Table 1 shows the acrylamide content in products from the Italian market. Fig. 1 shows a comparison between two GC/MS chromatograms concerning acrylamide determination in two samples cited in Table 1: (a) shows an amount less than $50 \mu \mathrm{g} / \mathrm{kg}$, and (b) shows a level of $124 \mu \mathrm{g} / \mathrm{kg}$.

\section{Discussion}

Results show a quantifiable increase of acrylamide level in risotto, compared to boiled rice, which leads to the conclusion that various ingredients used in the risotto contribute to the acrylamide levels. For tomato sauce, the increase of acrylamide level depends on the use of other ingredients such as olive and capers. In this study, tomatoes were not observed to produce significant levels of acrylamide after cooking and concentration. The use of tomato sauce, especially ready-to-use, can be considered the most preferable seasoning from this point of view. For various fast-food products, the detected level of acrylamide was not found to be as significant as expected. In accordance with previous studies, higher levels of acrylamide were detected for fried potatoes.

\section{Conclusions}

The conclusive considerations that can be drawn concern two topics, namely food safety and identification of the conditions that may result in production of acrylamide.

With respect to food safety, data on a common food in the Italian diet (rice and risotto), which occupy an important place in the diet, were studied for the first time. In other European countries rice does not represent a fundamental course, as it does in Italy, but is served as a side dish. Levels of acrylamide for rice and tomato sauce are not noteworthy as well for the definition of diets for children: to this end, it seems interesting to confirm a greater incidence of acrylamide assumption deriving from fast foods in the diet.

With reference to the information concerning influence of some ingredients used for seasoning, in this paper it was shown that the increase in acrylamide content in some cases may actually derive from the use of seasoning 

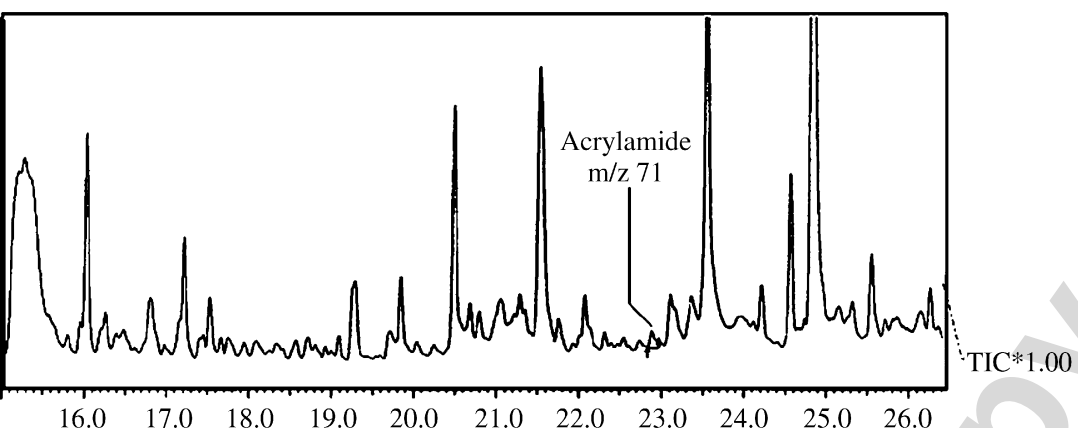

(A)

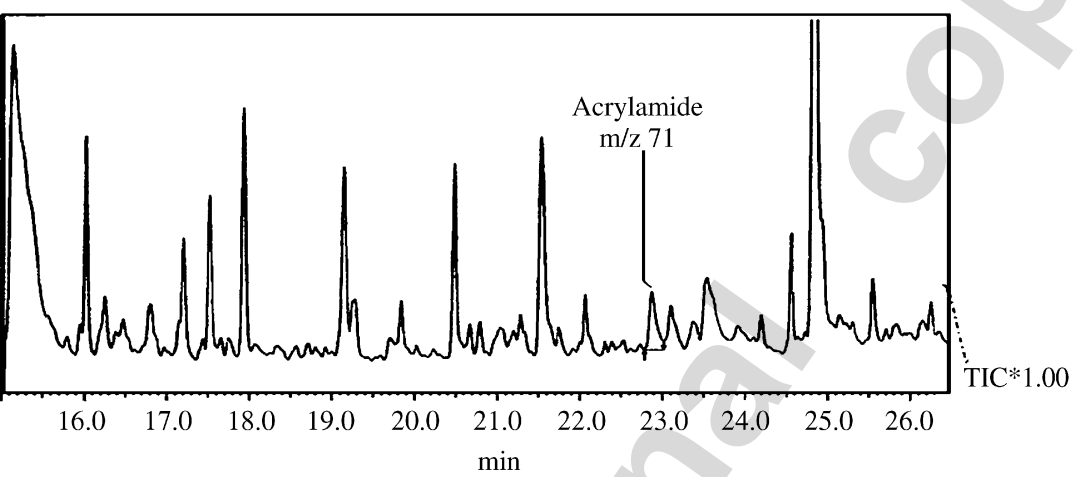

Fig. 1. Comparison of GC/MS traces (SIM mode, $m / z=71$ ) in two extracts from tomato sauces purchased on the Italian market (samples 9 and 10 , Table 1): (A) sauce "Pummarò Star" with fresh basil (acrylamide $<50 \mu \mathrm{g} / \mathrm{kg}$ ); (B) Knorr sauce with olives and capers (acrylamide $=124 \mu \mathrm{g} / \mathrm{kg}$ ).

ingredients, as a consequence of cooking operations (olives, capers, meat, olive oil, onion, dye, mushrooms).

Most importantly, considering real matrices, the formation of acrylamide was shown not to result from heating at moderate temperature and in the presence of water, as shown in the case of concentration to produce tomato sauce.

\section{References}

Bononi, M., Tateo, F., Andreoli, G., Varani, A., 2005. Determinazione dell'acrilammide in matrici alimentari contenenti suoi precursori. Industria Alimentara 443, 33-37.

Bull, R.J., Robinson, M., Laurie, R.D., Stoner, G.D., Greisiger, E., Meier, J.R.J., Stober, J., 1984. Carcinogenic effects of acrylamide in Senecar and $\mathrm{A} / \mathrm{J}$ mice. Cancer Research 44, 107-111.

Ezeji, T., Groberg, M., Qureshi, N., Blaschek, H., 2003. Continuous production of butanol from starch-based packing peanuts. Applied Biochemistry and Biotechnology 106, 375-382.
FDA (US Food and Drug Administration), 2004. Exploratory Data on Acrylamide in Food. US Dept. of Health and Human Services, Center for Food Safety and Nutrition. http://www.cfsan.fda.gov/ dms/ acrydata.html.

Friedman, M., 2003. Chemistry, biochemistry, and safety of acrylamide. A review. Journal of Agricultural and Food Chemistry 51 (16), 4504-4526.

IARC (International Agency for research on Cancer). 1994. Some Industrial Chemicals. http://www-cie.iarc.fr/monoeval/crthgr02a.html.

Tareke, E., Rydberg, P., Karlsson, P., Eriksson, S., Törnqvist, M., 2002. Analysis of acrylamide, a carcinogen formed in heated foodstuffs. Journal of Agricultural and Food Chemistry 50, 4998-5006.

Tateo, F., Bononi, M., 2003. Preliminary study on acrylamide in baby foods on the Italian market. Italian Journal of Food Science 15 (4), 593-599.

Törnqvist, M., Bergmark, E., Ehrenberg, L., Granath, F., 1998. Risk assessment of acrylamide. Report 7/98, Swedish Chemical Inspectorate, Solma. 